\title{
EXPERIMENTAL POLYARTHRITIS IN RATS INJECTED WITH A TUMOUR EXUDATE
}

\author{
BY \\ GAËTAN JASMIN \\ Institut de Médecine et de Chirurgie expérimentales, Université de Montréal, Canada
}

(RECEIVED FOR PUBLICATION MAY 12, 1957)

It has previously been observed that Murphy rat lymphosarcoma (MRLS) exudate collected from a tumour-pouch could cause typical proliferative arthritis in one or several joints (Jasmin and Richer, 1955). Such articular changes developed in a few days and were aggravated by adrenalectomy (Jasmin and Selye, 1955). It is the purpose of this communication to describe these pathological changes with reference to the regulatory action of the adrenocortical hormones. In addition, studies are reported on the inhibitory effect of oxytetracycline and sodium aurothiomalate and the isolation of a micro-organism as the causative agent.

\section{Material and Methods}

Female Sprague-Dawley rats, average body-weight of $160 \mathrm{~g}$., were used in these experiments. They received a "Purina Fox Chow" diet and tap water as drinking fluid. Bilateral adrenalectomy was performed and the hormonal therapy was started 48 hours before the injection of the exudate. Corticoids were injected subcutaneously once daily in the form of an aqueous microcrystal suspension at dosages indicated in the Tables.

The MRLS exudate was prepared as follows:

A neoplastic pouch was produced by injecting $0.5 \mathrm{ml}$. of a tumour cell suspension ( $1 \mathrm{~g}$. freshly ground tumour in $5 \mathrm{ml}$. physiological saline) into a $25-\mathrm{ml}$. air space under the connective tissue of the dorsal skin of the rat. After a lapse of 10 days-to allow for sufficient tumour develop- ment - an average volume of $10 \mathrm{ml}$. yellowish transparent fluid was withdrawn from the pouch under sterile conditions. This fluid was centrifuged to eliminate fibrin clots and tumour cells, and could be kept in the refrigerator without any decrease in potency for at least 20 days.

As illustrated in the Tables, readings of the lesions of the paws were made, at varying time intervals, according to a scale 0 to +++ . The severity of the inflammation was evaluated both in intensity and extent.

At the end of the experiments all animals were killed. Their joints were dissected, fixed in Susa solution, decalcified in sulphosalicylic acid for 3 days, trimmed, and stained by the haemotoxylin and eosin, and periodic acid Schiff techniques.

\section{First Experiment}

In this experiment $2 \mathrm{ml}$. fresh MRLS exudate were injected intravenously into intact and adrenalectomized rats receiving desoxycorticosterone acetate (DOC-Ac) or cortisol acetate (COL-Ac) as substitution therapy. We were thus permitted to make a comparative study of the regulatory effect of these corticoids on this particular type of inflammatory reaction. The experiment lasted 12 days.

Results.-As shown in Table I, articular lesions first appeared in the adrenalectomized, DOC-Ac treated animals (Group III), in which hyperaemia and tenderness of the paws were already demon-

TABLE I

EFFECT OF CORTICOIDS UPON THE DEVELOPMENT OF POLYARTHRITIS IN RATS INJECTED WITH A TUMOUR EXUDATE (MRLS)

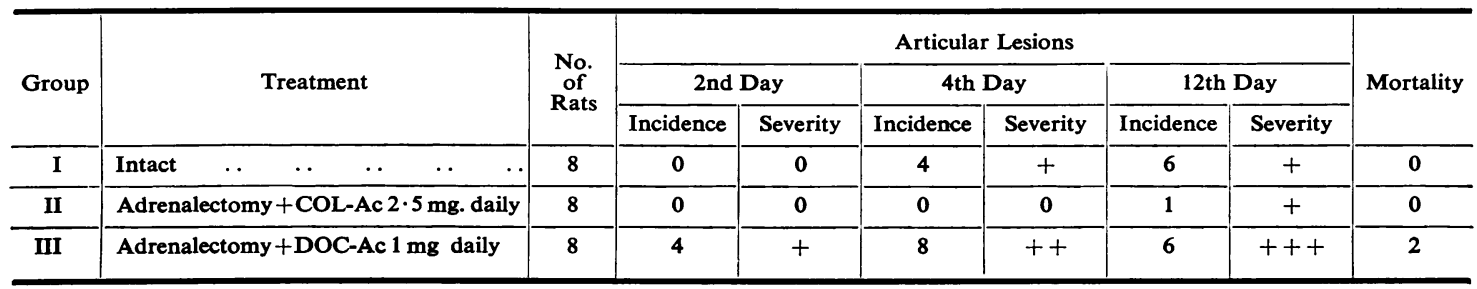


strable on the second day. Two days later, the intact animals (Group I) became reactive, but in a much more attenuated form. In this latter case, the inflammatory process was less diffuse and usually involved only a few extremities. Compared with the intact animals, the adrenalectomized, DOC-Ac-treated rats (Group III) were in a more serious condition; they were unable to stand, and in fact most of them were lying on their backs. When this happened special care was taken that these animals should have ready access to food. Conversely, in the adrenalectomized, COL-Actreated animals (Group II), no true articular inflammatory response was found at any stage of the experiment. However, in one animal of the latter group, there was a necrotic focus in the tarsal region of the hind paw, and in another, a paresis of the posterior limbs. It was noteworthy that, while the inflammatory process was in regression, the intact animals showed typical circumscribed lesions reminiscent of rheumatic nodules (Figs 1 and 2).
Pathological Findings.-At autopsy, all joints were carefully re-examined for possible inflammatory reactions which might have been overlooked during life. In addition, some of the internal organs which would be expected to show histological changes were removed and subjected to microscopic study. No further findings were revealed by this re-examination in the animals of Groups I and II. In the animals of Group III, the inflammatory process involved many more joints than those already noted. The most commonly affected were the tibiotarsus and radiocarpus, but other joints, such as the dorsal spine, elbows, knees, and hips, were also involved. Further, cyst-like formations were found on the ovaries, which, when the capsule was sectioned, liberated haemorrhagic viscous fluid. Most of the animals in this group showed urethritis and vaginitis. Also, when the dorsal skin was detached, it was seen that the connective tissue was intensely hyperaemic, and congested vessels could be followed into their smaller ramifications (Fig. 3, opposite).
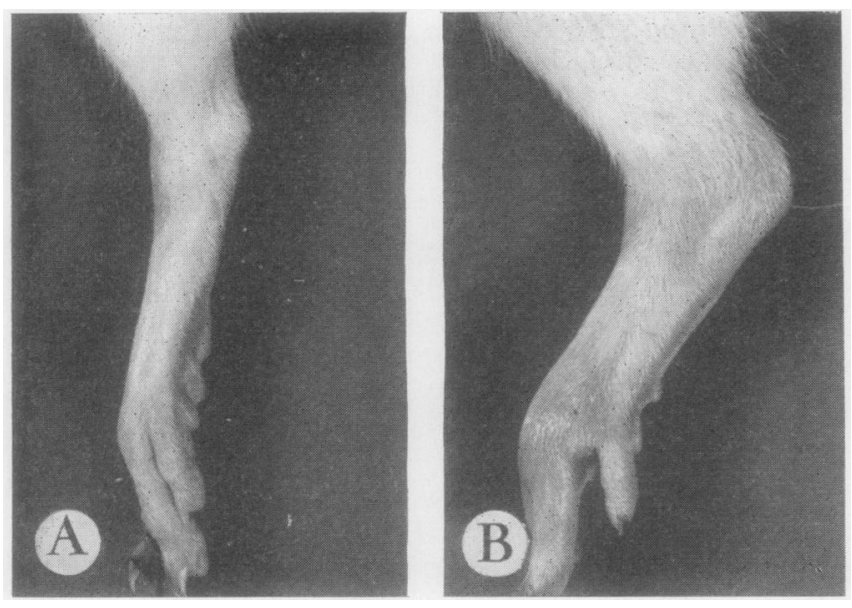

Fig. 1.-Macroscopic aspect of experimental polyarthritis induced by an intraperitoneal injection of MRLS exudate.

(A) Hind paw of an untreated rat.

(B) Typical arthritis as it occurs on the 3rd day following administration of exudate. Note the diffuse swelling and stiffness (thread pulling foot down fails to extend ankle joint fully, in treated rat).

(From Jasmin, G.: Ph.D. Thesis, Université de Montréal, 1955.)

Fig. 2.-Effect of corticoid hormones upon the development of polyarthritis induced by MRLS exudate.

(A) Intact rat otherwise untreated: the reaction is well circumscribed.

(B) Adrenalectomized, COL-Ac-treated rat: the reaction is prevented.

(C) Adrenalectomized, DOC-Ac-treated rat: the reaction is proliferative.

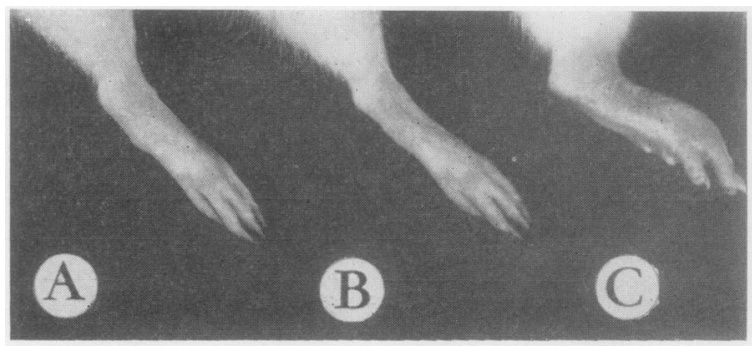



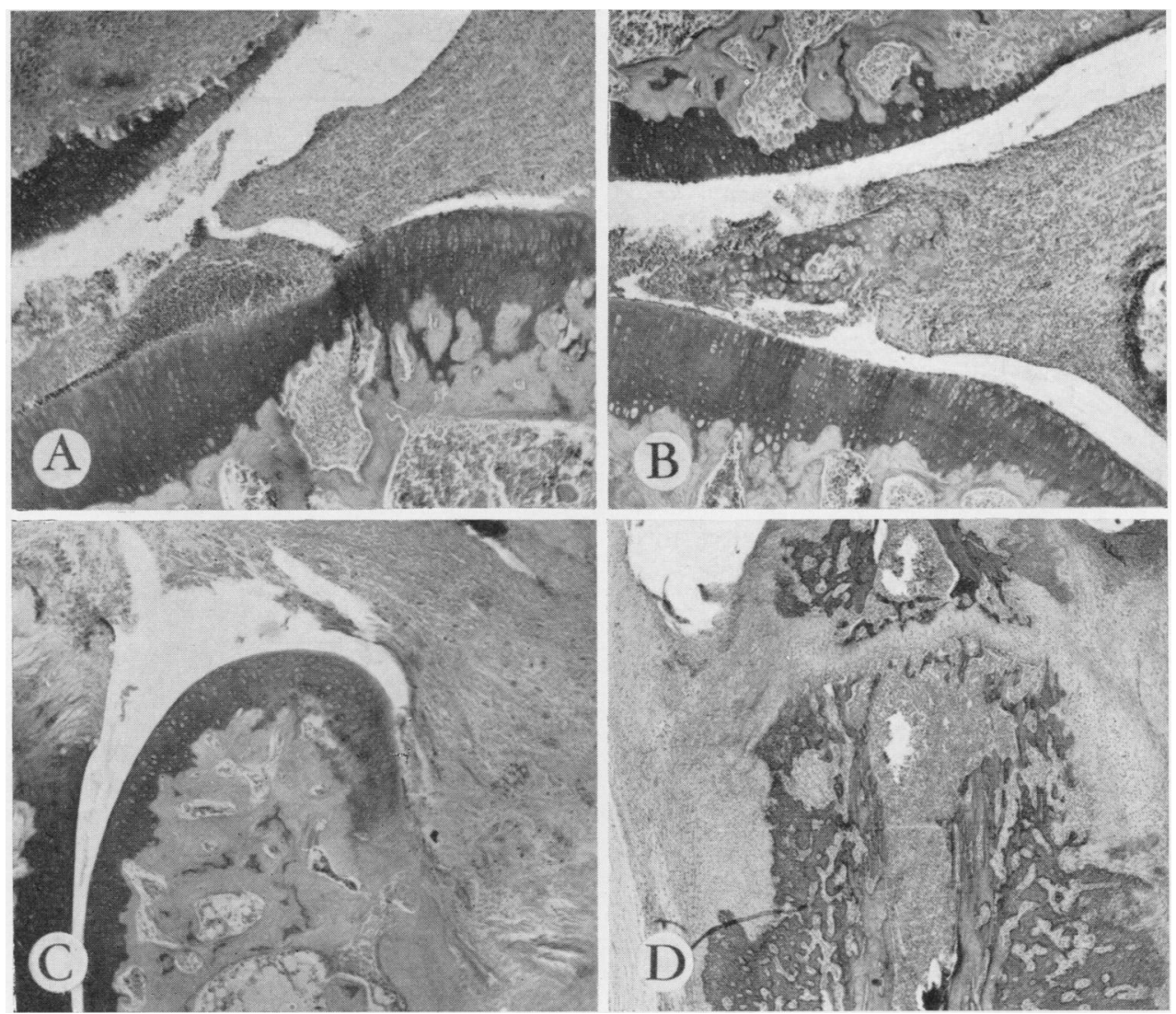

Fig. 3.-Histopathological changes observed in the knee joint of adrenalectomized, DOC-Ac-treated rats, killed between 8 to 15 days after injection of MRLS tumoral exudate.

(A) This section shows the intensely inflamed synovia which penetrates into the articular cavity. Note the erosion of the epiphyseal cartilage.

(B) A fibrocartilaginous pannus-like formation proliferating from the synovium.

(C) Periarticular granulation tissue surrounding the epiphysis to invade the cortical bone.

(D) Osteolytic process in the metaphysis with formation of immature cartilaginous cells originating from the epiphyseal disk.

Histological examination revealed varying degrees of pathological change in the joints. In the earlier stages, heavy cellular infiltrations, consisting mainly of lymphocytes and mononuclear leucocytes, were prominent in the synovia, and in many instances an erosion of the articular cartilage was noted. These pannus-like proliferations often turned into fibrocartilaginous tissue. Also, the inflammatory process of the peri-articular region occasionally invaded the cortical bone by surrounding the epiphysis. A particularly striking histological feature was the osteolytic process of the metaphysis with formation of immature cartilaginous cells originating from the epiphyseal disc. It was also observed that newlyformed periosteal spicules frequently protruded into the adjacent inflamed tissues. Furthermore, microscopic examination of the heart in many animals revealed endocardial and myocardial lesions similar to those found in rheumatic fever.

\section{Second Experiment}

This experiment was based on the observation that animals bearing MRLS tumours rarely show a spontaneous arthritis. To evaluate the relative extent of this self-protection by a specific immune factor originating from the tumoral transplanted tissue, or by the non-specific damage resulting from the tumour growth - which in turn would stimulate the adrenals to secrete antiphlogistic hormonesthe experiment was planned in the following manner:

The animals were first adrenalectomized and given substitution therapy of $100 \gamma$ of DOC-Ac and $200 \gamma$ of COL-Ac. This treatment proved to be effective 
PROTECTION AFFORDED BY HOMOLOGOUS TUMOUR TRANSPLANTATION IN ADRENALECTOMIZED CORTICOID-TREATED RATS INJECTED WITH MRLS EXUDATE

\begin{tabular}{|c|c|c|c|c|c|c|c|c|}
\hline \multirow{3}{*}{ Group } & \multirow{3}{*}{ Treatment } & & \multirow{3}{*}{$\begin{array}{l}\text { No. } \\
\text { of } \\
\text { Rats }\end{array}$} & \multicolumn{4}{|c|}{ Articular Lesions } & \multirow{3}{*}{ Mortality } \\
\hline & & & & \multicolumn{2}{|c|}{ 4th Day } & \multicolumn{2}{|c|}{ 8th Day } & \\
\hline & & & & Incidence & Severity & Incidence & Severity & \\
\hline I & Controls (Granuloma Pouch) & . & 8 & 8 & ++ & 7 & $+t+$ & 1 \\
\hline II & MRLS Transplantation & . & 8 & 0 & 0 & 0 & 0 & 1 \\
\hline
\end{tabular}

in restoring the inflammatory potential without any possible endogenous corticoid secretion.

A group of eight control rats was prepared with a granuloma pouch produced by $0.5 \mathrm{ml}$. of $0.5 \mathrm{per}$ cent. croton oil according to the usual technique (Selye and Jasmin, 1956). This inflammatory focus served as a control for a second group of rats which received a subcutaneous implantation of MRLS tissue. The exudate was administered intraperitoneally at a dose of $1 \mathrm{ml}$. and animals were under observation for the next 8 days.

Results.-As seen in Table II, the presence of MRLS tissue completely desensitized animals to the polyarthritic effect of MRLS exudate. The fact that this protection occurred in adrenalectomized animals, and that an inflammatory focus of a comparative size did not exert any similar action, led us to conclude that the factor involved was specific to the tumour.

\section{Third Experiment}

The previous experiments indicated that an immunological relationship existed between MRLS tumour and polyarthritis. Since a number of authors have already described a syndrome of polyarthritis in experimental animals injected with pleuropneumonia-like organisms (Findlay, Klieneberger, MacCullum, and Mackenzie, 1938; Sabin, 1939), and it has been shown that oxytetracycline and sodium aurothiomalate exert a therapeutic effect on these pathological changes (Sabin and Warren, 1940; Wichelhausen, Brown, Robinson, and Merchant, 1951; Kuzell, Gardner, Fairley, and Tripi, 1949), it was proposed to test these drugs for their ability to prevent the MRLS polyarthritis.

Each preparation was injected subcutaneously in the volume of $0.2 \mathrm{ml}$. twice daily for 8 days at the dosage indicated in Table III. The MRLS exudate was administered intraperitoneally on the first day in a volume of $1 \mathrm{ml}$.

Results.-These results made it increasingly evident that an infectious agent is concerned in the pathogenesis of the MRLS experimental arthritis. To substantiate such indirect evidence, we have been able to demonstrate that the tumour exudate is inactivated by a short exposure to ultra-violet rays and by the addition of a small quantity of nitromersol (Jasmin, 1956).

\section{Fourth Experiment}

Many long and searching courses were followed before we succeeded in isolating a micro-organism from the MRLS exudate. Various synthetic media were used for both aerobic and anaerobic cultures, as well as the one prepared specifically for PPLO identification*, without consistent results. Finally, using egg embryo, we obtained a positive growth which permitted us to identify some colonies $\dagger$.

* We wish to express our thanks to Dr. Irene Corey Diller of the Institute for Cancer Research and The Lankenau Hospital Research Institute, Philadelphia, for supplying us with these media.

+ The author is indebted to Dr. Paul Genest and Dr. Serge Renaud of the Collège Vétérinaire. St. Hyacinthe, Quebec. Canada, for their bacteriological studies.

EFFECT OF OXYTETRACYCLINE AND SODIUM AUROTHIOMALATE ON MRLS POLYARTHRITIS

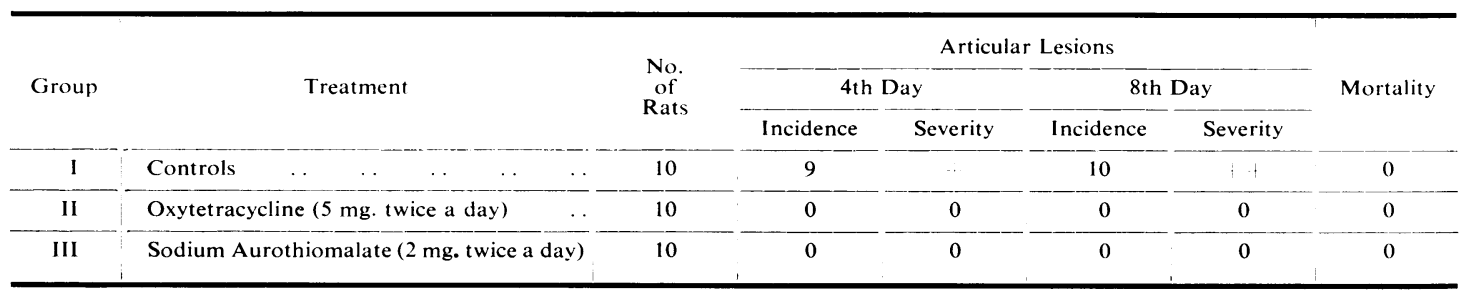


We inoculated 7-day incubated chick embryos in the vitelline membrane with $0.25 \mathrm{ml}$. of a $1: 10$ dilution of MRLS exudate; 24 hours after inoculation the membranes showed, on direct microscopic examination, branching filaments which were nonacid fast and Gram-positive. Most of the inoculated embryos died within 2 days. Examination of the membranes of the survivors after 3 to 5 days showed some fragmentation into bacillary and coccoid elements. This micro-organism resembles Nocardia asteroides (Renaud, Genest, and Jasmin, 1957).

After the first inoculation into chick embryos, no difficulty was encountered in obtaining subcultures on solid media. Tiny colonies were obtained whose size, pigmentation, and structure bore a striking similarity to those described by Klieneberger (1938) as being of the $\mathrm{L}_{4}$ strain.

To determine whether the infectious agent recovered from egg embryo culture is the MRLS polyarthritic factor, ten normal rats were injected intraperitoneally with various dilutions of a saline suspension of vitelline membrane as outlined in Table IV.

\section{TABLE IV}

POLYARTHRITIC RESPONSE IN RATS INJECTED INTRAPERITONEALLY WITH VARIOUS DILUTIONS OF A CULTURE OF MRLS EXUDATE

\begin{tabular}{cc|c|c|c|c}
\hline \multirow{2}{*}{ Group } & \multirow{2}{*}{ Dilutions } & \multicolumn{2}{|c|}{ Articular Lesions } & \multirow{2}{*}{ Mortality } \\
\cline { 3 - 5 } & & & 4th Day & 8th Day & \\
\hline I & $\cdots$ & $1: 100$ & 0 & + & 0 \\
\hline II & $\cdots$ & $1: 50$ & + & ++ & 0 \\
\hline III & $\cdots$ & $1: 20$ & + & ++ & 0 \\
\hline IV & $\cdots$ & $1: 10$ & + & +++ & 0 \\
\hline V & $\cdots$ & $1: 5$ & ++ & +++ & 0 \\
\hline
\end{tabular}

Results.-Examination of the readings, which were positive in every case, showed that $1 \mathrm{ml}$. of a $1: 50$ dilution is equal to $1 \mathrm{ml}$. of fresh exudate in its arthritis-producing properties ( $c f$. Group I, Table III; Group II, Table IV). Therefore, from our investigations so far, it may be concluded that the colonies obtained from egg embryo cultures include the MRLS polyarthritic factor.

\section{Discussion}

The present data suggest that the MRLS polyarticular syndrome is infectious in nature; yet the joint lesions, in that they are proliferative, seem different from those reported by Woglom and
Warren (1938), and by Parkes and Wrigley (1951).

These experimental lesions also differ from those reported by Kuzell and others (1949), and by Stoerk, Bielinsky, and Budzilovich (1954), in that they are influenced by adrenocortical hormones. Additional studies are in progress to establish whether Nocardia asteroides becomes pleomorphic, and is only pathogenic as regards the production of polyarthritis when in this state.

This possibility is suggested by the observation that the MRLS exudate remains active even after filtration through Zeiss U.F. fritted glass (Jasmin, 1956), and also that it is sensitive to antibiotics of the tetracycline series; these properties are characteristic of the majority of strains of pleuropneumonialike organisms (Robinson, Wichelhausen, and Brown, 1952).

On screening various transplantable tumour exudates for their polyarthritic effect, it was found that exudates from a mammary carcinoma, Novikoff hepatoma, and Croton-pouch-tumour No. 1 were all active. It remains to be seen whether or not the pathogenic agent is similar in each case.

Further, it was observed that a transplanted neoplasm showing no polyarthritic activity can be contaminated by the inoculation of a small amount of MRLS exudate during its growth (Jasmin, unpublished data). This indicates that the aetiologic agent is readily transmissible; even after many transplantations, the tumour retains its polyarthritic properties.

It may be recalled that some virus-like organism which produced a typical polyarthritis in rats (Woglom and Warren, 1938), was encountered in Sarcoma 39.

The pathogenesis of the MRLS lesions could perhaps also be explained on the ground of a hypersensitivity phenomenon. A number of authors have described a syndrome of polyarthritis in rats which occurred after a subcutaneous or intracutaneous injection of Freund's adjuvant, the potency of which was augmented by adding spleen or macerated striated muscle extract to the inoculum (Stoerk and others, 1954; Pearson, 1956). Since this emulsion activates immune reactions only (Freund and McDermott, 1942; Fischel, Kabat, Stoerk, Skolnick, and Bezer, 1954; Freund, 1956), it may be postulated that the resulting inflammatory response in the joint is related to a selective tissue hypersensitiveness. The latter assumption is substantiated by the fact that in our experience, dextran, which usually causes only a transient anaphylactoid reaction in the rat, proved to aggravate the polyarthritis when added to MRLS exudate (Jasmin, 1956). 


\section{Summary}

An experimental polyarthritis in rats has been induced by a single intravenous or intraperitoneal injection of Murphy rat lymphosarcoma (MRLS) exudate.

(1) In animals deprived of their adrenals, the joint lesions were shown to be aggravated by desoxycorticosterone acetate (DOC-Ac) and prevented by cortisol acetate (COL-Ac).

(2) Rats transplanted with MRLS and receiving an homologous exudate were protected against such lesions. This fact does not seem to be related to adrenal function since it occurred in adrenalectomized animals receiving both corticoids as substitution therapy.

(3) It was further observed that oxytetracycline and sodium aurothiomalate were effective in preventing the development of polyarthritis.

(4) Cultures obtained from incubated eggs injected with MRLS exudate have permitted us to isolate a pleomorphic micro-organism resembling Nocardia asteroides which, when injected intraperitoneally into rats, produced the same polyarthritic syndrome.

Such generalized articular inflammatory reaction provided a model for the study of the processes which culminate in the polyarthritic disease.

These investigations were subsidized by a grant from the Canadian Arthritis and Rheumatism Society and the Foundation Joseph Rhéaume. The author is indebted to the Pfizer Laboratory for the cortisol acetate (Cortril) and for the oxytetracycline (Terramycin), to the Schering Corporation for the desoxycorticosterone acetate (Cortate) and to the Poulenc Laboratory for the sodium aurothiomalate (Myocrysine).

\section{REFERENCES}

Findlay, G. M., Klieneberger, E., MacCallum, F. O., and Mackenzie, R. D. (1938). Lancet, 2, 1511.

Fischel, E. E., Kabat, E. A., Stoerk, H. C., Skolnick, M., and Bezer, A. E. (1954). J. Allergy, 25, 195.

Freund, J. (1956). Fortschr. TuberkForsch., 7, 130.
and McDermott, K. (1942). Proc. Soc. exp. Biol. (N.Y.) 49, 548.

Jasmin, G. (1955). Ph.D. Thesis, Montreal.

(1956). Rev. canad. Biol., 15, 107.

- Bois, P., and Selye, H. (1955). "Proc. First Canadian Conference on Research in Rheumatic Diseases, Toronto." Abs. Annals of the Rheumatic Diseases (1956), 15, 269. Annals of the Rheumatic Diseases (1956), 15, 269.
and Richer, L. (1955). Rev. canad. Biol., 14, 118.

and Richer, L. (1955), Rev. Canad. Biol., 14,
Klieneberger, E. (1938). J. Hyg. (Camb.), 38, 458.

Kuzell, W. C., Gardner, G. M., Fairley, De Lorez M., and Tripi, H. B.", (1949). In "Rheumatic Diseases", based on the proceedings of the 7th International Congress on Rheumatic Diseases, p. 409 . Saunders, Philadelphia.

Parkes, M. W., and Wrigley, F. (1951). Annals of the Rheumatic Diseases, 10, 177.

Pearson, C. M. (1956). Proc. Soc. exp. Biol. (N.Y.), 91, 95.

Renaud, S., Genest, P., and Jasmin, G. "The Isolation, Cultivation and Pathogenicity of Nocardia asteroides recovered from the Murphy Rat Lymphosarcoma." (In preparation.)

Robinson, L. B., Wichelhausen, R. H., and Brown, T. McP. (1952). J. Lab. clin. Med., 39, 290.
Sabin, A. B. (1939). Science, 89, 228.

and Warren, J. (1940). J. Bact., 40, 823.

Selye, H., and Jasmin, G. (1956). Ann. N.Y. Acad. Sci., 64, 481.

Stoerk, H. C., Bielinski, T. C., and Budzilovich, T. (1954) Am. Ass. Pathol. and Bacteriol. Meet., Philadelphia, April 8-10.

Wichelhausen, R. H., Brown, T. McP., Robinson, L. B., and Merchant, W. R. (1951). Annals of the Rheumatic Diseases, $10,463$.

Woglom, W. H., and Warren, J. (1938). J. exp. Med., 68, 513.

\section{Polyarthrite expérimentale des rats par iniection} d'exsudat tumoral

RÉSUMÉ

On provoquait une polyarthrite expérimentale chez rats par une seule injection intraveineuse ou intrapéritonéale d'exsudat de lymphosarcome de rat de Murphy (MRLS).

(1) Chez les animaux privés de leur surrénales, les lésions articulaires étaient aggravées par l'acétate de desoxycorticostérone (DOC-Ac) et empêchées par l'acétate de cortisone (COL-Ac).

(2) Les rats auxquels on avait greffé un MRLS et recevant un exsudat homologue, se trouvaient protégés contre la polyarthrite. Ce fait ne semble pas être lié à la fonction surrénale, car il se produisait chez des rats surrénalectomisés recevant les deux corticoïdes comme thérapie de remplacement.

(3) On a vu aussi que l'oxytetracycline et l'aurothiomalate de soude étaient efficaces pour prévenir la polyarthrite.

(4) Des cultures obtenues d'oeufs incubés et injectés d'exsudat de MRLS nous ont permis d'isoler un organisme pléomorphe ressemblant à Nocardia asteroides qui, injecté intrapéritonéalement au rat, produisait le même syndrome polyarthritique.

Ce type de réaction inflammatoire articulaire général isée a fourni un modèle pour l'étude des processus quō̄ aboutissent à la maladie polyarthritique.

\section{Poliartritis experimental de ratas por inyección de exudado tumoral \\ SUMARIO}

Se provocó una poliartritis experimental en ratas por una sola inyección endovenosa $o$ intraperitoneal de exudado de linfosarcoma de rata de Murphy (MRLS).

(1) En los animales suprarrenoprivos, las lesiones articulaires fueron agravadas por el acetato de desoxicorticoesterona (DOC-Ac) e impedidas por el acetato de cortisona (COL-Ac).

(2) Las ratas injertadas con un MRLS, al recibir un exudado homólogo, viéronse protegidos contra la poliartritis. Este hecho no parece estar ligado a la función suprarrenal, ya que ocurría en las ratas suprarrenoprivas recibiendo ambos corticoides como terapia de substitución.

(3) Se observó también que la oxitetraciclina y el aurotiomalato de sodio fueron eficaces en impedir la poliartritis.

(4) Culturas obtenidas de huevos incubados e inyectados con el exudado de MRLS nos permitieron aislar un organismo polimorfo, parecido a Nocardia asteroides, el cual inyectado intraperitónealmente a la rata, producía el mismo sindrome poliartrítico.

Este tipo de reacción inflamatoria articular generalizada nos dió un modelo para estudiar los procesos que acaban en la enfermedad poliartrítica. 